\title{
Volatility, island nations and small states
}

\author{
Jeffrey A. Edwards ${ }^{1, *}$ • Alfredo A. Romero ${ }^{2}$ \\ ${ }^{1}$ Department of Economics, North Carolina Agricultural and Technical State University, Greensboro, USA \\ ${ }^{2}$ North Carolina Agricultural and Technical State University, Greensboro, USA
}

Received: 6 September 2019

Revised: 19 February 2020

Accepted: 26 February 2020

\begin{abstract}
The authors of this paper have attempted to fill a gap in the literature that addresses both domestic and foreign born growth volatility for island countries and small states. Using a sophisticated dynamic panel framework, we find that the characteristics of both types of volatility are considerably different than they are for other countries. Our results argue against the prevailing wisdom regarding volatility that these two groups should simply mimic the economic policies of other nations.
\end{abstract}

Keywords: volatility; growth; small states; islands

JEL Classification Codes: F02, F42, C10

\section{Introduction}

The economics literature on island nations and small states ${ }^{1}$ is quite large. Topics run the gamut from economic growth, to investment, trade, agriculture, fishing, migration, to tourism (Chen and Singh 2016, Jayaraman et al. 2016, Casey and Hamilton 2014, Schiff 2014, Mahadevan and Asafu-Adjaye 2013, Schiff and Wang 2013, Jayaraman and Lau 2011, Hansen and Headey 2010, Gani and Clemes 2010, Narayan et al. 2010, Chowdhury 2008, Prasad 2008, Seetanah et al. 2008, Kida 2005, Fairbairn 2002). On the subject of growth, there seems to be what we would consider three glaring omissions.

While researchers investigate growth volatility, with few exceptions (e.g., Mapp and Moore 2015, Jackman et al. 2009), they seem to always (i) disregard its dynamics and (ii) pay only cursory statistical attention to how shocks in these nations compare to others. Both of these characteristics are important because they allow administrators to better customize policy prescriptions. At least equally important, however, is the question that (iii) given the size and geographical isolation of these nations relative to others, exactly how much volatility is coming from the rest of the world? Current literature simply lumps all volatility into one broad category,

\footnotetext{
* Corresponding author. E-mail: jaedwar2@ncat.edu.
}

Citation: Edwards, J. A., and Romero, A. A. (2020) Volatility, island nations and small states, Economics and Business Letters, 9(3), 248-254.

DOI: $10.17811 /$ ebl.9.3.2020.248-254

${ }^{1}$ Countries with less than one million people which includes the bulk of island nations as well. 
regardless of whether it is home grown or foreign born. Policy prescriptions one would use to address internal shocks might be considerably different than policy used to address external shocks, especially for countries with limited resource bases like these small and/or island states.

Small state and island nation researchers have argued that growth volatility is greater in these countries, but Easterly and Kraay (2000) find no evidence that greater volatility translates into greater economic vulnerability. In fact, they state that in general small states "are no different than large states and should receive the same policy advice." We believe this view is somewhat misguided. First, while some small states/islands have high GDP per capita (Chowdhury 2008), there exists some evidence that poverty levels seem to be higher (World Bank 2000), and therefore, should be disproportionally affected by high volatility (de Ferranti et al. 2000). Second, the International Monetary Fund delineates the characteristics that make these nations different: narrow production bases, big governments, poorly integrated financial sectors, fixed exchange rates, and trade openness (Jahan and Wang 2013)--many of these areas are targeted by policymakers. Hence, if these countries differ from other nations in these areas is it also logical to conclude that their policies should be the same?

To the authors of this paper, it is obvious that there is a gap to fill in the literature regarding growth volatility dynamics and the impact that volatility has in these unique economies relative to those in the rest of of the world.

\section{Methods}

Our model takes the general form

$$
\text { Volatility }_{i t}=a_{i 0}+\sum_{g=1}^{5} \sum_{k=1}^{2}\left(a_{g k} \text { Volatility }_{i t-k}+b_{g k} \text { World Volatility }_{t-k+1}\right)+e_{i t}
$$

In words, volatility in country $i$ at time $t$ is regressed on country specific fixed effects, the first and second lag of itself, and current and lagged volatility from the rest of the world; the lag period for each is one year. The lag length for the dependent variable was chosen based upon the statistical significance of the lag itself, while the first two years of world volatility are included simply because any policy response would either be synchronus with current events, or at most, a response to events just passed. The volatility variable(s) are constructed as the natural log of the absolute deviation from the long run growth rate (the long run growth rate is simply the mean growth rate across all available years for that country). Constructing the variable in this way allows for a greater frequency of observations and therefore more data points. ${ }^{2}$ The subscript $g$ represents the country groupings island or small state, and development level. The reader will notice that the variable World Volatility does not have an individual subscript, $i$, only a time subscript, $t$. This variable is constructed as the log of the mean level of volatility across all nations that are not in group $g$, and are not in the island or small states group during time period $t$. In other words, this is volatility from the rest of the world when the coefficient for group $g$ is being estimated.

Because of the standard endogeneity issues that result from a dynamic panel with fixed effects (Edwards 2014), and because our world volatility measure is possibly endogenous, we exploit a system GMM estimation procedure (Blundell and Bond 1998) that will generate instruments for each. Our conditioning set is small, but is still too large to use an unrestricted GMM method as the number of instruments would quickly grow and over-specification would be an issue

\footnotetext{
${ }^{2}$ Edwards JA (e.g., 2016, 2011) is probably the best known for using this proxy for volatility.
} 
(Roodman 2006). ${ }^{3}$ To circumvent this problem, we create one instrument for each right-hand side variable and lag distance instead of for each variable, lag distance, and time period. We also use a finite-sample correction to the two step covariance matrix by Windmeijer (2005), and test for second-order serial correlation (first-order is expected given the design of the method). A Hansen test will check for independence between the residuals and the lagged and contemporaneous variables. Both Fuller (1996) and Phillips/Perron (1988) tests were used to check for a unit root in volatility, even though the results below indicate that the coefficients on lagged volatility sum to far less than one for all groups. These tests are preferable to other tests as they do not require strongly balanced panels. Both tests return a p-value of 0.000 in all cases, thus rejecting the null that a unit root exists.

\section{Data}

All data comes from the World Bank's World Development Indicators dataset. ${ }^{4}$ To match previous work, the list of small states comes from Easterly and Kraay (2000), while the list of island nations comes from the United Nations' list of Small Island Developing States. ${ }^{5}$ The number of small state countries with available data for this project is thirty, and for islands it is forty-five which includes members and non-members of the UN (see Appendix for listing of each). The panels are unbalanced starting in 1960 and ending in 2017. Since we are comparing GDP growth volatility, and since some island nations have large populations making population level comparisons impossible, we compare our estimates to other countries grouped by development level in terms of average per capita real GDP according to the World Bank: under $\$ 1026$ (low), $\$ 1026$ to $\$ 4035$ (lower middle), $\$ 4036$ to $\$ 12475$ (upper middle), and over $\$ 12475$ (high income). ${ }^{6}$

The question of whether island nations require their own category has been around for several decades. Since 1992, the United Nations Conference on Environment and Development (UNCED) recognize small island developing nations as a special case of small countries--we simply continued with this demarcation. Different from small states, small islands also exhibit little resilience to natural disasters and fragility of their natural environment. Additionally, their small domestic market is heavily dependent upon relatively few external markets, exhibit higher costs for energy, infrastructure, transportation, communication and servicing, in addition to being relatively far from export markets. For these reasons, we study them as a separate group.

\section{Results}

Table 1 lists the estimates for the first set of regressions for small states and their respective pvalues in parentheses. The numbers in the brackets are the p-values comparing the small state estimates to the other groups. Table 2 lists the same for island nations. Statistics in the bottom rows of each table show that our regressions all cover 8332 observations and 204 countries and dependent territories (e.g., British Virgin Islands are not considered a country, but a territory), have 31 instruments each which is well under the number of countries (Roodman 2006), are comprehensively significant as the Wald statistic is quite high, have first order error dependence which is expected (AR(1)), second order error independence which is also expected for a properly specified model $(\mathrm{AR}(2))$, and no feedback from the instruments to the volatility

\footnotetext{
${ }^{3}$ The program we use was constructed by David Roodman of the Center for Global Development in Washington, DC, and is not the same program found canned in Stata--this one is more sophisticated and more flexible.

${ }^{4}$ https://databank.worldbank.org/source/world-development-indicators

${ }^{5} \mathrm{https}: / /$ sustainabledevelopment.un.org/topics/sids/list

${ }^{6}$ We use per capita real GDP instead of GNI like the World Bank, giving us more observations. The two are correlated nearly one-for-one, but GNI has limited availability.
} 
variables with a Hansen p-value well above zero but not close to one (a p-value close to one would indicate overspecification).

What we see in Table 1 is that domestic volatility amongst small states has a memory of roughly two years (the third lag was not significant and is not shown here) unlike the other groups, and the estimate for the second lag is significantly larger than the other groups. We also find that shocks from the rest of the world are slightly more than one-for-one, but only last for one period unlike two of the four income groups, and is also significantly different than three of the four groups.

Table 1. Small States Coefficient Estimates \& Comparison P-values.

\begin{tabular}{|c|c|c|c|c|c|}
\hline & Small States & Low & Low Middle & Upper Middle & High \\
\hline Volatilityit-1 $_{\text {in }}$ & $\begin{array}{l}0.120 * * \\
(0.002)\end{array}$ & $\begin{array}{l}0.099 * * \\
(0.011) \\
{[0.710]}\end{array}$ & $\begin{array}{l}0.205 * * \\
(0.000) \\
{[0.076]^{*}}\end{array}$ & $\begin{array}{l}0.062 \\
(0.193) \\
{[0.348]}\end{array}$ & $\begin{array}{l}0.175 * * \\
(0.000) \\
{[0.273]}\end{array}$ \\
\hline Volatilityit-2 $_{\text {in }}$ & $\begin{array}{l}0.099 * * \\
(0.006)\end{array}$ & $\begin{array}{l}0.011 \\
(0.747) \\
{[0.088]^{*}}\end{array}$ & $\begin{array}{l}0.022 \\
(0.408) \\
{[0.087]^{*}}\end{array}$ & $\begin{array}{l}0.014 \\
(0.644) \\
{[0.079]^{*}}\end{array}$ & $\begin{array}{l}0.013 \\
(0.688) \\
{[0.085]^{*}}\end{array}$ \\
\hline WorldVol $_{t}$ & $\begin{array}{l}1.115 * * \\
(0.000)\end{array}$ & $\begin{array}{l}0.820 * * \\
(0.007) \\
{[0.400]}\end{array}$ & $\begin{array}{l}0.838 * * \\
(0.002) \\
{[0.393]}\end{array}$ & $\begin{array}{l}0.969 * * \\
(0.007) \\
{[0.730]}\end{array}$ & $\begin{array}{l}1.542 * * \\
(0.000) \\
{[0.207]}\end{array}$ \\
\hline WorldVol $_{\mathrm{t}-1}$ & $\begin{array}{l}0.193 \\
(0.435)\end{array}$ & $\begin{array}{l}0.794 * * \\
(0.001) \\
{[0.004]^{* *}}\end{array}$ & $\begin{array}{l}0.537 * * \\
(0.021) \\
{[0.082]^{*}}\end{array}$ & $\begin{array}{l}0.076 \\
(0.794) \\
{[0.658]}\end{array}$ & $\begin{array}{l}-0.278 \\
(0.285) \\
{[0.047]^{* *}}\end{array}$ \\
\hline \# Obs & 8332 & Wald(20) & 215.97 & AB AR(1) P & 0.000 \\
\hline \# of I's & 204 & Wald P & 0.000 & $\mathrm{AB} A R(2) \mathrm{P}$ & 0.363 \\
\hline \# Inst & 31 & & & Hansen $\mathrm{P}$ & 0.527 \\
\hline
\end{tabular}

$*$ implies significance at $10 \%, * *$ at $5 \%$

Table 2. Island Coefficient Estimates \& Comparison P-values.

\begin{tabular}{l|l|l|l|l|l}
\hline \hline & \multicolumn{1}{l}{ Islands } & \multicolumn{1}{l}{ Low } & \multicolumn{1}{l}{ Low Middle } & \multicolumn{1}{l}{ Upper Middle } & \multicolumn{1}{l}{ High } \\
\hline Volatility-1 & $0.114 * *$ & $0.091 * *$ & $0.225 * *$ & 0.068 & $0.163 * *$ \\
& $(0.002)$ & $(0.018)$ & $(0.000)$ & $(0.176)$ & $(0.000)$ \\
& & {$[0.665]$} & {$[0.016]^{* *}$} & {$[0.452]$} & {$[0.298]$} \\
Volatility-2 & 0.047 & 0.004 & 0.031 & 0.022 & 0.029 \\
& $(0.115)$ & $(0.888)$ & $(0.294)$ & $(0.507)$ & $(0.422)$ \\
& & {$[0.365]$} & {$[0.713]$} & {$[0.592]$} & {$[0.700]$} \\
World Vol $\mathrm{t}_{\mathrm{t}}$ & $1.221 * *$ & $0.680 * *$ & $0.881 * *$ & $0.829 * *$ & $1.312 * *$ \\
& $(0.000)$ & $(0.022)$ & $(0.001)$ & $(0.027)$ & $(0.000)$ \\
& & {$[0.154]$} & {$[0.335]$} & {$[0.394]$} & {$[0.804]$} \\
World Vol $\mathrm{t}_{-1}$ & 0.213 & $0.754 * *$ & $0.421 *$ & 0.082 & -0.190 \\
& $(0.360)$ & $(0.001)$ & $(0.083)$ & $(0.779)$ & $(0.453)$ \\
& & {$[0.008]^{* *}$} & {$[0.302]$} & {$[0.628]$} & {$[0.074]^{*}$} \\
\hline \# Obs & 8332 & Wald(20) & 194.53 & AB AR(1) & 0.000 \\
\# of I's & 204 & Wald & 0.000 & AB AR(2) & 0.547 \\
\# Inst & 31 & & Hansen & 0.718 \\
\hline \hline
\end{tabular}

* implies significance at $10 \%, * *$ at $5 \%$ 
The Island estimates in Table 2 tell a slightly different story. Domestic volatility has a memory of roughly one year, which is the same as three other groups, even though significantly higher than upper middle income countries. Contemporaneous world volatility affects island countries by about one-tenth more than Small States, but again, the memory is only for one year, which is significantly different than two of the four other groups.

The longer memory result in small countries is interesting. As argued above, in general, small nations might be more prone to volatility shocks due to their narrow productions bases, big governments, financial systems, etc. Under this framework, however, it is entirely possible that the land-locked nature of many small states, as opposed to small island nations, places them in a position of being a recipient of lingering volatility from nations directly abutting theirs. This spillover effect would likely not be as pronounced in island countries simply because of their oceanic buffer.

\section{Concluding remarks}

The authors of this paper have attempted to fill a gap in the literature that addresses real GDP growth volatility for both island countries and small states. Using a more sophisticated form of the popular dynamic panel GMM estimation technique that takes into consideration the number of instruments relative to the number of countries, thus limiting possible bias in the estimators, we find considerable difference in both domestic volatility dynamics and how external shocks affect these groups of countries relative to others. Specifically, we find that mimicking international policy addressing cycles in growth volatility are better suited for islands, but not for small states, while policy addressing the impact from external shocks should should be highly customized for each group.

\section{References}

Blundell R. W., and Bond, S. R. (1998) Initial Conditions and Moment Restrictions in Dynamic Panel Data Models, Journal of Econometrics, 87(1), 115-143.

Casey, S. R., and Hamilton, R. T. (2014) Export performance of small firms from small countries: The case of New Zealand, Journal of International Entrepreneurship, 12(3), 254269.

Chen, H., and Singh, B. (2016) Output impacts of the interaction between foreign direct investment and domestic credit: Case study of Pacific Island countries, Studies in Economics and Finance, 34(3), 331-343.

Chowdhury, A. (2008) Growth Oriented Macroeconomic Policies for Small Islands Economies: Lessons from Singapore, UNU World Institute for Development Economics Research. Research Paper No. 2008/47.

de Ferranti, D., Perry, G., Gill, I., and Serven, L. (2000) Securing Our Future in a Global Economy. Washington DC, World Bank.

Easterly, W., and Kraay, A. C. (2000) Small States, Small Problems? Income, Growth, and Volatility in Small States, World Development, 28(11), 2013-2027.

Edwards, J. A. (2014) Building Better Econometric Models Using Cross Section and Panel Data, Business Expert Press, New York, NY.

Edwards, J. A., Romero, A. A., and Sadjadi, Z. M. (2016) Foreign Direct Investment, Economic Growth and Volatility: a useful model for policymakers, Empirical Economics, 51(2), 681705. 
Edwards, J. A., and Ginn, V. (2011) Evaluating Growth Volatility Susceptibility within Regional Free Trade Agreements, International Journal of Finance \& Economics, 16(1), 32-40.

Fairbairn, T. I. J. (2002) Pacific Island Economies: Performance, Growth Prospects and the Impact of the Asian Economic Crisis, Asian-Pacific Economic Literature, 13(2), 43-56.

Fuller, W. (1996) Introduction to Statistical Time Series, Second Edition, John Wiley, NY.

Gani, A., and Clemes, M. D. (2010) Service and economic growth in Pacific Island countries, International Journal of Development Issues, 9(2), 113-130.

Hansen, H., and Headey, D. (2010) The Short-Run Macroeconomic Impact of Foreign Aid to Small States: An Agnostic Time Series Analysis, Journal of Development Studies, 46(5), 877-896.

Jackman, M., Craigwell, R., and Moore, W. (2009) Economic volatility and remittances: evidence from SIDS, Journal of Economic Studies, 36(2), 135-146.

Jahan, S., and Wang, K. (2013) A Big Question on Small States, International Monetary Fund, Finance \& Development, 50(3), 44-47.

Jayaraman, T. K., and Lau, E. (2011) Oil Price and Economic Growth in Small Pacific Island Countries, Modern Economy, 2(2),153-162.

Jayaraman, T. K., Choong, C. K., and Chand, P. (2016) Do Foreign Aid and Remittance Inflows Hurt Competitiveness of Exports of Pacific Island Countries? An Empirical Study of Fiji, Journal of Economic Development, 41(2), 111-125.

Kida, M. (2005) Caribbean Small States - Growth Diagnostics, The World Bank http://siteresources.worldbank.org/INTDEBTDEPT/Resources/4689801206974166266/4833916-1206989877225/KidaSmallStates.pdf

Mahadevan, R., and Asafu-Adjaye, J. (2013) Exploiting comparative advantage in agriculture and resources: the way forward for Small Island States, The Australian Journal of Agricultural and Resource Economics, 57(3), 320-343.

Mapp, T., and Moore, W. (2015) The informal economy and economic volatility, Macroeconomics and Finance in Emerging Market Economies, 8(2), 185-200.

Narayan, P. K., Narayan, S., Prasad, A., and Prasad, B. C. (2010) Tourism and economic growth: a panel data analysis for Pacific Island countries, Tourism Economics, 16(1), 169183.

Phillips, P. C. B., and Perron, P. (1988) Testing for a Unit Root in Time Series Regression. Biometrika 75, 335-346.

Prasad, B. C. (2008) Institutions, good governance and economic growth in the Pacific Island countries, International Journal of Social Economics, 35(12), 904-918.

Roodman, D. (2006) How to Do xtabond2: An Introduction to 'Difference' and 'System' GMM in Stata, Stata Journal, 9(1), 86-136.

Schiff, M. (2014) Small States, Micro States, and their International Negotiation and Migration, Journal of Economic Integration, 29(3), 430-449.

Schiff, M., and Wang, Y. (2013) North-South Trade-related Technology Diffusion and Productivity Growth: Are Small States Different?, International Economic Journal, 27(3), 399-414.

Seetanah, B., Ramessur, S. T., and Rojid, S. (2008) Financial development and economic growth: New evidence form a sample of island economies, Journal of Economic Studies, 36(2), 124-134.

Windmeijer, F. (2005) A Finite Sample Correction for the Variance of Linear Efficient Twostep GMM Estimators, Journal of Econometrics 126(1), 25-51.

World Bank (2000) Small States: Meeting Challenges in the Global Economy. Report of the Commonwealth Secretariat / World Bank Joit Task Force on Small States. 


\section{Appendix A - List of countries}

Islands (United Nations SIDS List)

Aruba

American Samoa

Antigua and Barbuda

Bahrain

Bahamas, The

Belize

Bermuda

Barbados

Comoros

Cabo Verde

Cuba

Dominica

Dominican Republic

Fiji

Micronesia, Fed. Sts.

Guinea-Bissau

Grenada

Guam

Guyana

Haiti

Jamaica

Kiribati

St. Kitts and Nevis

St. Lucia

Maldives

Marshall Islands

Northern Mariana Islands

Mauritius

Nauru

Palau

Papua New Guinea

Puerto Rico

Singapore

Solomon Islands

Sao Tome and Principe

Suriname

Seychelles

Timor-Leste

Tonga

Trinidad and Tobago

Tuvalu

St. Vincent and the Grenadines

Virgin Islands (U.S.)

Vanuatu

Samoa
Small States (Easterly and Kraay (2000))

Antigua and Barbuda

Bahrain

Bahamas, The

Belize

Bermuda

Barbados

Comoros

Cabo Verde

Cyprus

Djibouti

Fiji

Gabon

Gambia, The

Guinea-Bissau

Grenada

Guyana

Iceland

St. Kitts and Nevis

St. Lucia

Luxembourg

Maldives

Malta

Mauritius

Qatar

Solomon Islands

Suriname

Seychelles

St. Vincent and the Grenadines

Vanuatu

Samoa 